\title{
El FIT de Cádiz: entre la teatralidad y la academia
}

\section{Enrique Mijares}

Al cabo de treinta ediciones, el Festival Iberoamericano de Teatro que se realiza anualmente en la milenaria ciudad de Cádiz sigue gozando de cabal salud y renovados bríos en lo que corresponde al ámbito teatral, esto es, creativo, espectacular.

El balance que en su momento solicitara Juan Villegas a Pepe Bablé es positivo. Aunque no ha sido director del FIT sino del '89 en adelante, pues antes lo fueron Juan Margallo y José Sanchis Sinisterra, Bablé está satisfecho del diverso racimo programático con el que ha sabido complacer al abanico de públicos. Satisfacción no sólo de los propios creadores participantes que acuden a las salas desde todos los rumbos de las dos orillas, sino de los genuinos espectadores del evento: los habitantes de Cádiz. Además y no menos relevante, el aspecto económico registra un logro insólito: este año, afirma Bablé, el festival se realiza con el mismo presupuesto que en 1989.

De forma paralela a la programación espectacular se realiza el encuentro "Cruce de criterios", donde se leen algunas ponencias que dan cuenta del devenir de estas tres décadas. De carácter estadístico, la mayoría de las disertaciones revisa los diversos aspectos no tanto estéticos del FIT sino en relación a los porcentajes de participación que han tenido los distintos países en el devenir programático del longevo festival.

Un repaso de los temas que a lo largo de los nueve años han convocado a participar en la actividad paralela del Cruce de criterios muestra la claridad de propósitos de su coordinador, Eberto Ruiz Abreu, una intencionalidad que podemos agrupar en dos grandes rubros. El primero son los que se refieren a la identidad, la territorialidad, las fronteras, y las crisis políticas y económicas que enfrentan los países iberoamericanos, tanto en particular como en conjunto. El segundo son los relacionados con los procesos creativos propiamente dichos, en específico aquellos que diversifican la actividad 
de los espectadores, ya no simples receptores como quería la modernidad unidireccional, sino en su calidad de creadores.

Se trata, podemos colegir de lo anterior, de un periodo de análisis que centra la atención en la creación, incluyendo en esta función - junto a los autores, directores y actores - a los "críticos" y a los "especialistas". Por lo menos en esta ocasión, el apartado denominado Foros de Creadores - dedicado precisamente a charlar con los integrantes de los grupos invitados, así directores y actores como responsables de los aspectos técnicos - presenta puntos no débiles sino marcadamente ajenos al quehacer teatral visto desde el cuerpo mismo del fenómeno creativo. Según afirma en entrevista electrónica Ruiz Abreu, el Cruce de criterios debiera ser, "no una suerte de congreso de académicos que se reúnen, investigan y escriben para dictar cátedra de su saber, sino una suerte de diálogo cercano a la creación y a sus riesgos, sus procesos, y no sólo a sus atípicos resultados en una noche de festival, que por demás, nada tiene que ver con el cuerpo y la vida natural de un espectáculo y sus espectadores de origen".

Los ejemplos atestiguados en dichos foros denotan ignorancia supina por parte de quienes se atribuyen la función de criticar de manera erudita, que llaman académica, las puestas en escena, cuando algunos de ellos únicamente tienen la experiencia del aula donde "analizan" textos dramáticos. Es decir, son profesores que se ciñen a preceptivas literarias y desconocen el proceso performático de la creación teatral.

Sin detenerme en la reseña pormenorizada de la excelente programación del 2015, en esta ocasión el FIT de Cádiz contó con la puesta en vigor de las tragedias ejemplares: Edipo, creación colectiva de la Companhia do Chapitò de Portugal, y Otelo, adaptación y dirección de Gabriel Chamé de Argentina, dos hazañas asaz divertidas y por ende, extremadamente reflexivas y polisémicas. Ambas propuestas apoyan la creación en el teatro físico, el clown y la hilaridad. La vuelta de tuerca que ello proporciona al relato escénico hace posible que el espectador, por obra y gracia del remedio infalible de la risa, actualice sin dolor y sin resaca el análisis acerca de los grandes dilemas que enfrentan los seres humanos de todos los tiempos. En el primer caso son parricidio e incesto, en el segundo caso celos y feminicidio, dilemas que en el ámbito cotidiano eufemísticamente se les disfraza mediante la negación y/o la simulación.

Pues bien, la eficaz realización de estas dos extraordinarias creaciones puso en evidencia los preocupantes visos de anquilosamiento, mejor dicho, de ausencia analítica, de comprensión elemental del fenómeno escénico por 
parte de algunos académicos. Estos miembros de la academia desconocen la distancia que media entre la literatura dramática y la índole eminentemente convivial de un acontecimiento llamado "teatro" desde sus orígenes, esto es, mirador, el lugar de los espectadores, sin cuya mirada simple y llanamente no hay teatro.

Los tres actores de Otelo, pongamos por caso, quienes "actúan sin protección" todos los personajes de la historia - a luz general, en el escenario vacío como pidiera Peter Brook y con ropa cotidiana sin cambios ni accesorios - fueron sometidos al siguiente cuestionario: ¿Cómo hacen ustedes para ocupar el espacio? ¿Cómo logra cada actor representar sucesivamente diversos personajes sin apenas transición entre uno y otro? Por pudor prefiero considerar ingenuas las preguntas, porque no es que pasen por alto sino que sencillamente ignoran que la creación teatral descansa en la convención, cifra primera y última de su naturaleza proteica, reflexiva, dialéctica y sistémica. Esto es, desconocen que el teatro es polisemia pura.

Preocupante, en efecto, la distancia de lenguajes se acentúa cuando Juan Villegas, académico de probada capacidad investigadora — quien tuvo a su cargo durante la última década del siglo pasado el equipo de análisis académico del FIT - inquiere a uno de los ponentes acerca del concepto "crisis" en el título de su ponencia, "La crisis del texto en los 30 años del FIT de Cádiz", al tiempo que le pregunta: “¿Qué entiende usted por teatro de calidad?"

El cuestionado fue José Luis García Barrientos. Por cierto, en su libro de método Cómo se comenta una obra de teatro (2012), García Barrientos pretende hacer caber a toda costa en una estructura lineal de unidades aristotélicas y escenificación realista Luces de Bohemia, obra que instaura el esperpento como hipertexto constituido por infinidad de espacios, tiempos, personajes e intertextos. García Barrientos responde a Villegas que "[e]mpleo el término 'crisis' sólo como un recurso provocador". Y afirma que "[p]ara mí teatro de calidad es aquel que cuando salimos de la función, todos coincidimos en que nos gustó".

¿O sea que según él, se trata de un nivel condicionado al 'consenso' y no de un fenómeno estético-social y dialógico que promueve discusión, invita a la reflexión, y aspira al apropiamiento y a la complementariedad creadora por parte del público?

Los escenarios de Cádiz 2015 se llenan de teatro en toda su magnitud porque las propuestas confluyen en la actualización de los temas, la puesta en vigor de los recursos metodológicos y la innovación de los lenguajes. 
Dan sobrada constancia de ello, además de las mencionadas Otelo y Edipo: Algernón. La angustia del conocimiento del colectivo Arte Matamala de Chile; El grito en el cielo de la proverbial agrupación artística La Zaranda y Libertino, magistralmente bailado por Chloé Brùlé y Marco Vargas, ambos grupos de España; y Cuando todos pensaban que habiamos desaparecido de Vaca 35 de México. Al dialogar con los creadores, la academia permanece adocenada, decimonónica, todavía aupada en el sitial efímero de autoridad que le otorgara la posmodernidad finisecular y sin dar visos de reconocer que desde hace tres lustros hemos entrado de lleno en el siglo digital, cibernético e hipertextual de hoy.

Tal vez, sólo tal vez, esas personas no se han percatado de la importancia que García Abreu concede a la recepción, a cuya perspectiva está orientada la temática relacionada con el espectador que aparece en las diversas emisiones del Cruce de criterios: "Prácticas creadoras de formación y reinvención de los espectadores. Grupos y teatralidades en la construcción de nuevas relaciones entre la escena, la realidad y los espectadores. Creación teatral y crítica: las miradas del espectador. Los estudios sobre el público. El espectador (el crítico y la crítica) como dramaturgos de la escena: Encargos y posibilidades de intervención del espectador en el acontecimiento escénico."

Lo dicho al inicio. Al cabo de treinta veces, tres décadas para la comprensión del mejor teatro hecho en las dos orillas, para el FIT de 2015 no se hace una edición conmemorativa sino simplemente se le da la continuidad requerida a una programación que refleja la vitalidad actual del teatro iberoamericano, tal como afirma su director, "[dando] mayor atención a espectáculos lúdicos pero sin olvidar nuestro compromiso con las nuevas dramaturgias, teatralidades y los lenguajes contemporáneos". El FIT de Cádiz goza de cabal salud en el ámbito de la creación escénica y le deseamos larga y fecunda vida futura.

Sistema Nacional de Creadores de Arte

Universidad Juárez del estado de Durango 